\title{
Production and Characterization of Exopolygalacturonase for Fusarium oxysporum and F. sacchari
}

\author{
Liqaa Y. Mohsen ${ }^{1}$, Jawad K. A. Al-Janabi ${ }^{2}$, Mohammad A. Jebor ${ }^{3}$ \\ ${ }^{1,2,3}$ Department of Biology, College of Science, University of Babylon, Iraq
}

\begin{abstract}
These experiments were conducted to study the production; purification, characterization, and molecular identification of Polygalacturonase enzyme from $F$. oxysporum and $F$. sacchari were investigated. The results showed that the optimum incubation period for Polygalacturonase in F. oxysporum and F. sacchari were occurred within two days. Polygalacturonase exhibited maximal activity at $\mathrm{pH} 6,27^{\circ} \mathrm{C}$ and $0.5 \%$ pectin concentration. The results revealed that the best ratio for exo Polygalacturonase precipitation for $F$. oxysporum and $F$. sacchari was 70 and $90 \%$ of ammonium sulphate respectively. Two peaks of PG were appeared in ion exchange chromatography purified from F.oxysporum. While in case of $F$. sacchari, only three peaks of protein and one peak of enzyme activity were shown The results showed that the molecular weight of Polygalacturonase from F. oxysporum (two peaks) using SDS-PAGE were approximately $53 \mathrm{KD}$, and about $41 \mathrm{KD}$ for PG purified from F.sacchari under denaturation conditions. For characterization of Polygalacturonase purified from F.oxysporum, the results reported the highest activity of PG (A) occurred at pH 5 while peak (B) was showed highest activity at $\mathrm{pH}$ 6. On other hand, the maximum enzyme activity of Polygalacturonase in F. sacchari was obtained at pH 5. Best growth (two peaks) achieved at $40^{\circ} \mathrm{C}$ for $\mathrm{F}$. oxysporum and $45^{\circ} \mathrm{C}$ for $\mathrm{F}$. sacchari respectively. Finally, molecular identification of exo Polygalacturonase gene in F. oxysporum and F. sacchari was investigated using PCR technique. The PCR primers designed from the conserved region of known fungal produced $1700 b$ product from the genomic DNA of F.oxysporum and 1200 bp product from the genomic DNA of F.sacchari.
\end{abstract}

Keywords: Purification, polygalacturonase enzyme, molecular identification of pgx1 gene.

\section{Introduction}

Fungi can produce wide extracellular enzymes, especially Fusarium species; these are used to break down complex polysaccharides into simple sugars to be important and used for growth and reproduction. These enzymes are very important in an industry of detergent, starch, drinks, food, textile, animal feed, chemicals and bio medical products. These enzymes include, protease, cellulase, chitinase, lipase, and pectinase are found [1,2]. Pectin is an important structural component of primary cell walls and middle lamella providing firmness and organization to plant tissue [3]. Pectinase is one of the most of important enzymes that contribute to the degradation of pectin by various mechanisms. The family of pectinase consists of protopectinase, polygalacturonase, lyase and methyl esterase. Polygalcturonase is used to cleavage of the polygalactyronic acid with the introduction of water across the oxygen bridge. Based on the mode of action, polygalacturonase are classified into two groups ,(i) endo polygalacturonase (E.C.3.2.1.15) that used to breakdown the polymer chain in a random pattern liberating saturated oligogalacturonides and galacturonic acid (ii) exopolygalacturonase (E.C.3.2.1.67) split the polymer bonds releasing one saturated galacturonic acid residue from nonreducing end of homogalacturonan. Polygalacturonase are one of the most important pathogenicity factors for fungi such as Aspergillus flavus, Alternaria citri and Fusarium oxysporum, in addition to some genera of bacteria such as Agrobacterium tumefaciens [4]. The characterization of purified polygalacturonase is an important that used for research since it exhibited on being able to distinguish between the enzymatic complex components of the substrate degradation mechanisms, optimum conditions for enzymatic activity and the regulation of enzyme by inhibiters [5]

\section{Material and Methods}

\section{Source of organisms:}

The species of Fusarium are obtained from the Unit of Advanced Mycology / Department of Biology / College of Science/ University of Babylon / Autum 2013.

\section{Preparation of Fusarium oxysporum and Fusarium sacchari Inoculum}

Pure culture of newly isolated $F$. oxysporum and $F$. sacchari was maintained on PDA slants at $4{ }^{\circ} \mathrm{C}$, synthetic medium was autoclaved for $15 \mathrm{~min}$, cooled then the flasks $(250 \mathrm{ml}$ size), were inoculated by placing $10 \mathrm{~mm}$ agar medium plugs containing active mycelium (5 days old) from each of F.oxysporum and F.sacchari growing in slant culture. Flasks were incubated at $28^{\circ} \mathrm{C}$ on a rotary shaker at $150 \mathrm{rpm}$ for 5 days.

\section{Isolation of polygalacturonase enzyme}

At the end of fermentation, the mycelium was separated from the culture broth by filtering through filter paper (Whatman No.1), the filtrate was centrifuged at 10,000 rpm for $20 \mathrm{~min}$ at $4{ }^{\circ} \mathrm{C}$ to remove the suspended particles, and the supernatant was carefully collected and stored under refrigerated conditions for further purification steps after enzyme assay.

Measuring the activity of polygalacturonase enzyme The reaction mixture contained $0.1 \mathrm{ml}$ of the enzyme, $0.8 \mathrm{ml}$ of citrus pectin substrate; $0.1 \mathrm{ml}$ of acetate buffer $(\mathrm{pH}$ 


\section{International Journal of Science and Research (IJSR) \\ ISSN (Online): 2319-7064 \\ Index Copernicus Value (2013): 6.14 | Impact Factor (2014): 5.611}

5.6).The mixture was incubated for 20 minutes at $40^{\circ} \mathrm{C}$. After incubation period, $1 \mathrm{ml}$ of DNS was added and the mixture heated at boiling for 5 minutes in water bath to develop the color. After cooling in room temperature, the optical density was measured in triplicate at $560 \mathrm{~nm}$ using spectrophotometer. Absorbance was used to calculate the activity of enzyme using the formula:-

$$
\text { Enzyme activity } \mathrm{U} / \mathrm{ml}=\frac{\text { O.D }}{0.01^{\star} \text { Time }^{*} \text { volume (crude enzyme) }}
$$

\section{Purification of polygalacturonase}

\section{Ammonium sulphate precipitation}

The crude polygalacturonase solution was precipitated by different concentrations of (NH4)2SO4 (20, 30, 40, 50, 60, 70,80 and $90 \%$ ) under cooled conditions, the precipitates were separated by centrifugation at $8000 \mathrm{rpm}$ for 30 minutes and dissolved in small amount of acetate buffer solution prepared in (3.8.1.4) The final volume of solution, the activity of enzyme and protein concentration was measured and specific activity was calculated. The protein concentration was determined by Bradford method (1976).

\section{Separation of enzyme through DEAE - cellulose}

Enzyme solutions $(3 \mathrm{ml})$ that produced after precipitation step was loaded in ion exchange column .The column was washed with $0.1 \mathrm{M}$ of acetate buffer at flow rate $30 \mathrm{ml} /$ hours and eluted with gradient $(1 \mathrm{M}-0.1 \mathrm{M})$ of $\mathrm{NaCl}$ solution. Fractions of $3 \mathrm{ml} /$ tube were collected and the optical density at $280 \mathrm{~nm}$ was measured, enzyme activity was measured at the peak fractions with high polygalacturonase activity were collected, volume enzyme activity and protein concentration was determined.

\section{Gel filtration chromatography technique}

\section{Enzyme separation through sephadex G-200}

The enzyme solution separated from ion exchange chromatography was added gently on the surface of gel, the elution was achieved by using acetate buffer at flow rate 30 $\mathrm{ml} /$ hour (3 $\mathrm{ml}$ for each fraction), the protein fractions was measured at $280 \mathrm{~nm}$, the enzymatic activity was measured of fractions, then collected the activation parts and measured the activity, volume and protein concentration, divided in vials and stored in freeze to the following experiments.

\section{SDS-Polyacrylamide Gel Electrophoresis (PAGE)}

SDS-PAGE was performed to check the homogeneity of the enzyme on a $10 \%, 15 \%$ gel (Laemmli, 1970) and molecular weight determined by standard protein marker. The protein bands on gel were visualized by staining it with Coomassie brilliant blue R- 250 .

\section{Characterization of polygalacturonase enzyme}

\section{Optimum pH of enzyme activity}

The substrate pectin for polygalacturonase was prepared with different $\mathrm{pH}$ ranges by using acetate buffer $0.1 \mathrm{M}(\mathrm{pH}=$ $4.5,5,5.5$, and 6$)$, phosphate buffer $0.1 \mathrm{M}(\mathrm{pH}=6.5,7,7.5)$ and Tris Hcl buffer $0.1 \mathrm{M}(\mathrm{pH}=8,8.5,9,9.5$ and 10), the purified enzyme was added and reaction solution was incubated at $40{ }^{\circ} \mathrm{C}$ for 20 minutes, after then reaction was stopped by adding $1 \mathrm{ml}$ of DNS reagent in boiling water bath. The enzyme activity was estimated and the reaction was drawn between enzyme activity and $\mathrm{pH}$ ranges to determine optimal $\mathrm{pH}$ for enzyme activity.

\section{Optimum temperature of enzyme activity}

The substrate pectin for polygalacturonase enzyme was prepared at PH 5.8 for F.oxysporum and pH 5 for F.sacchari in tubes, the tubes were incubated at different temperatures $(30,35,40,45,50,55,60$, and 65$){ }^{\circ} \mathrm{C}$ for 40 at $10 \mathrm{~min}$ for mixing, after then purified enzyme was added and incubated for $20 \mathrm{~min}$ to start the reaction, the activity was estimated and the reaction was drawn between enzyme activity and different temperature.

\section{Molecular characteristic of Fusarium species}

\section{DNA extraction kit solution}

These methods were determined according to SolGent Company.

\section{Results}

\section{Purification of polygalacturonase enzyme}

The ammonium sulphate used in different saturation ratios $(20,30,40,50,60,70,80$, and $90 \%)$, then the $70 \%$ ratio and $90 \%$ for F.oxysporum and F.sacchari was selected as best ratio for precipitate the crude extract of enzyme in the first step respectively, followed by Ion exchange chromatography two peaks of protein and enzyme activity appeared in the eluted fractions from F.oxysporum that shown in figure (1) The first peak of protein with specific activity $3.4 \mathrm{U} / \mathrm{mg}$ with purification fold 5.1 and yield $44.3 \%$, while the second peak of protein has specific activity $26.4 \mathrm{U} / \mathrm{mg}$ with purification fold 39.4 and yield $37.8 \%$ that showed in table 1 . In the state of F.sacchari, the results in figure (2) showed appearance of three beak of protein with enzyme activity .It was obtained one peak of protein after concentrated with specific activity $0.3 \mathrm{U} / \mathrm{mg}$ with purification fold 2.1 and yield $36.8 \%$ that showed in table 2 . The enzyme solution obtained from ion exchange chromatography was passed through sephadex G200 column $(1.5 * 85) \mathrm{cm}$ that equilibrated with acetate buffer $(0.1 \mathrm{M}, \mathrm{pH} 5.6)$, the fraction were collected and measured at $280 \mathrm{~nm}$ absorbency. One peak of protein with one peak of enzyme activity was appeared, as shown in figure (3). This peak of protein has specific activity $0.7 \mathrm{U} / \mathrm{mg}$ with purification fold 4.2 and yield $34.3 \%$, shown in table (2). SDS PAGE electrophoresis of purified enzyme revealed five samples, first sample was crude enzyme extract while other sample produced from ion exchange (peak A and B) these samples belong to $F$,oxysporum has molecular weight 53 $\mathrm{KD}$ (figure 4). In the state of F.sacchari revealed four samples, first sample was crude extract enzyme, second sample was precipitation of ammonium sulphate, third sample produced from ion exchange and the four sample produced from gel filtration (figure 5). The optimum $\mathrm{pH}$ for PG enzyme activity (2 peaks) purified from F.oxysporum showed in (figure 6), peak A has enzyme activity $18.9 \mathrm{U} / \mathrm{ml}$ at $\mathrm{pH} 5$ while peak B has optimum activity $19.6 \mathrm{U} / \mathrm{ml}$ at $\mathrm{pH}$ 6. F.sacchari showed in (figure 7) has maximum enzyme activity at pH $520.4 \mathrm{U} / \mathrm{ml}$. The optimum temperature for PG enzyme activity (peak A and B) purified from F.oxysporum showed in (figure 8), peak A has enzyme activity $18 \mathrm{U} / \mathrm{ml}$ at

\section{Volume 5 Issue 1, January 2016}




\section{International Journal of Science and Research (IJSR) \\ ISSN (Online): 2319-7064 \\ Index Copernicus Value (2013): 6.14 | Impact Factor (2014): 5.611}

temperature $40^{\circ} \mathrm{C}$ while peak $\mathrm{B}$ has optimum activity $17.5 \mathrm{U} / \mathrm{ml}$ at temperature $40^{\circ} \mathrm{C}$.. F. sacchari showed in (figure 9) has maximum enzyme activity $23.4 \mathrm{U} / \mathrm{ml}$ at temperature $45^{\circ} \mathrm{C}$

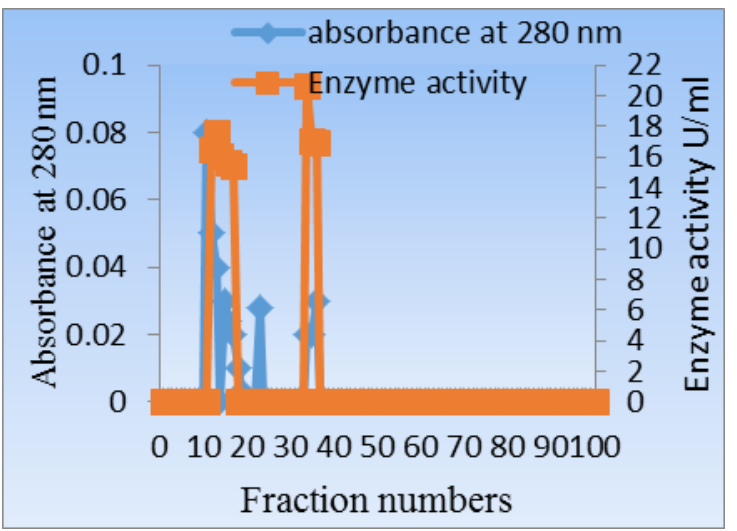

Figure 1: Ion exchange chromatography using DEAEcellulose column $(2.8 \times 18) \mathrm{cm}$ with acetate buffer $(0.1 \mathrm{M}, \mathrm{pH}$ 5.6), for purification from F.oxysporum polygalacturonase enzyme from $F$.oxysporum

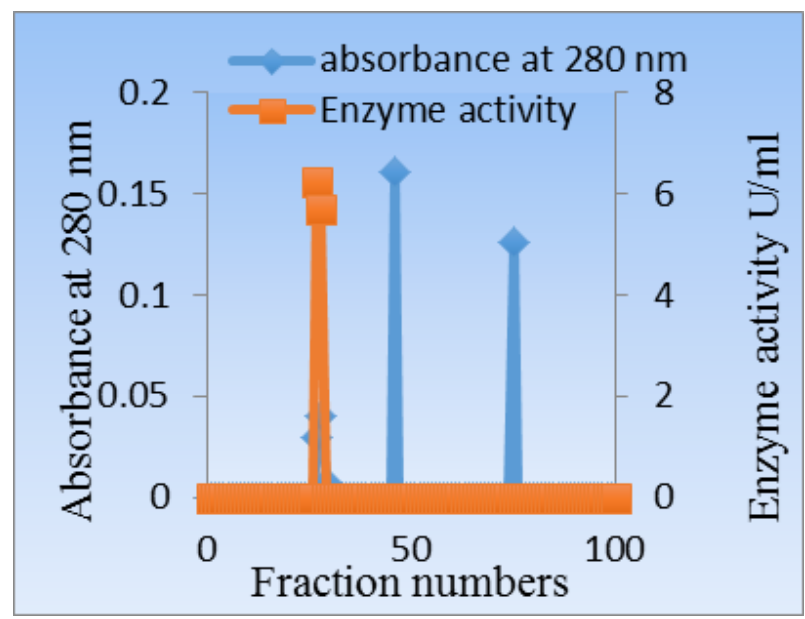

Figure 2: Ion exchange chromatography using DeaeCellulose column $(2.8 \times 18) \mathrm{cm}$ with acetate buffer (0.1M, pH 5.6), for purfication from $F$. sacchar polygalacturonase enzyme

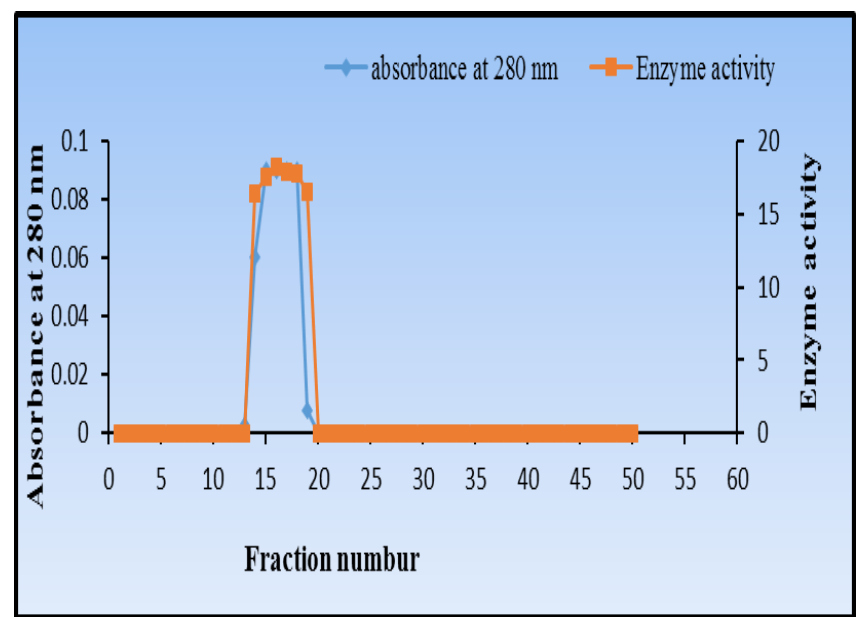

Figure 3: Gel filtration uses sephadex G-200 column $(1.5 \times 85 \mathrm{~cm}) \mathrm{cm}$ with acetate buffer $(0.1 \mathrm{M}, \mathrm{pH} 5.6)$, for purification polygalacturonase enzyme from $F$.sacchari

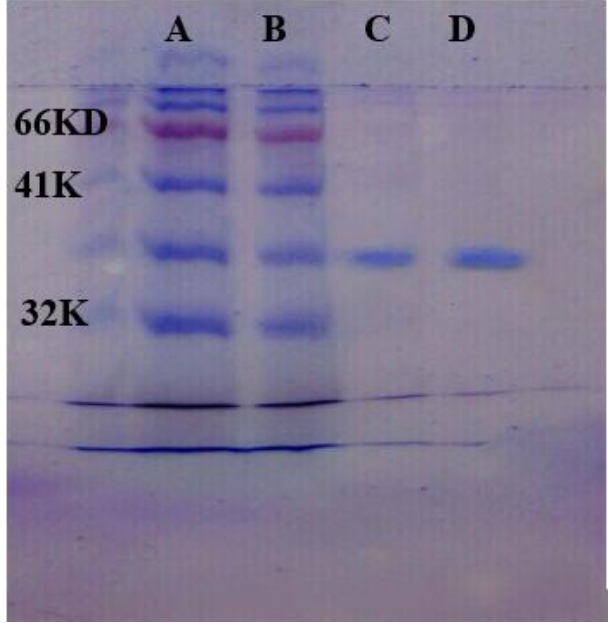

Figure 4: Polyacrylamide gel electrophoresis of the Polygalacturonase from $F$.oxysporum since $A=$ molecular weight marker, $\mathrm{B}=$ crude extract enzyme, $\mathrm{D}=$ represents the purified enzyme produced from Ion exchange chromatography

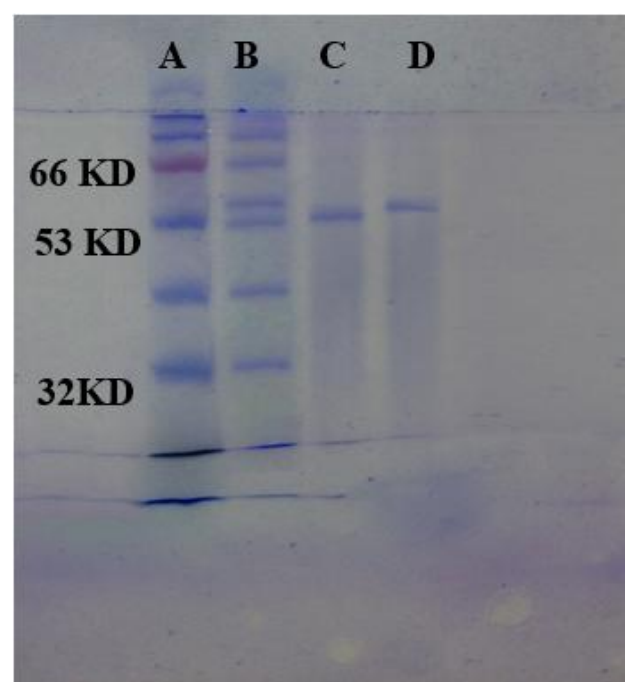

Figure 5: Polyacrylamide gel electrophoresis of the Polygalacturonase from $F$. sacchari since $\mathrm{A}=$ molecular weight marker, $\mathrm{B}=$ crude extract enzyme, $\mathrm{C}$, =represents the purified enzyme produced from Ion exchange chromatography. and $\mathrm{D}=$ Purified enzyme produced from Gel filtration.

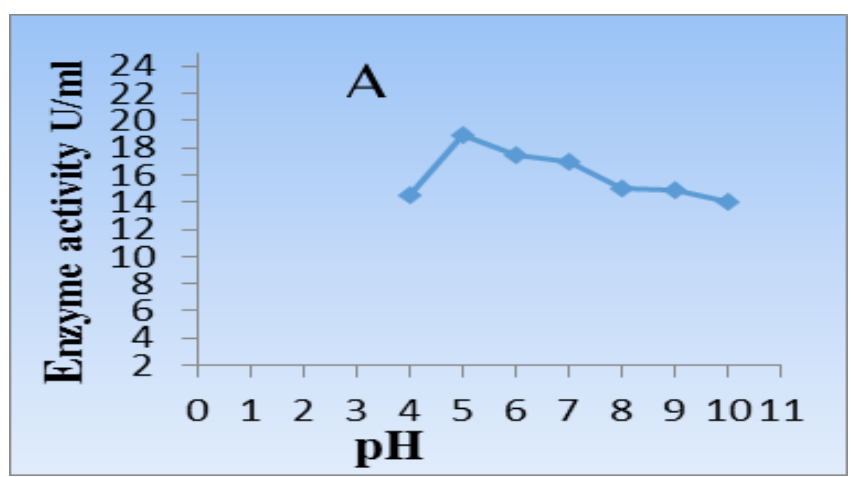




\section{International Journal of Science and Research (IJSR) \\ ISSN (Online): 2319-7064}

Index Copernicus Value (2013): 6.14 | Impact Factor (2014): 5.611

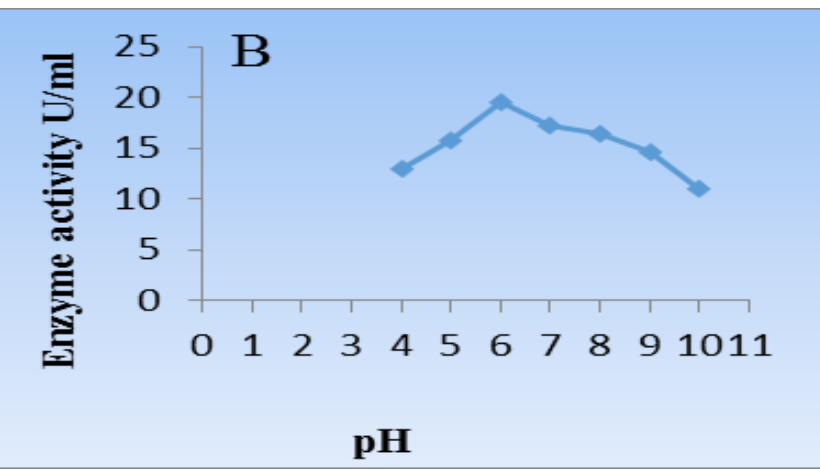

Figure 6: Effect of $\mathrm{pH}$ value on the polygalacturonase activity purified from F.oxysporum. $\mathrm{A}=$ peak 1 and $\mathrm{B}=$ peak 2.

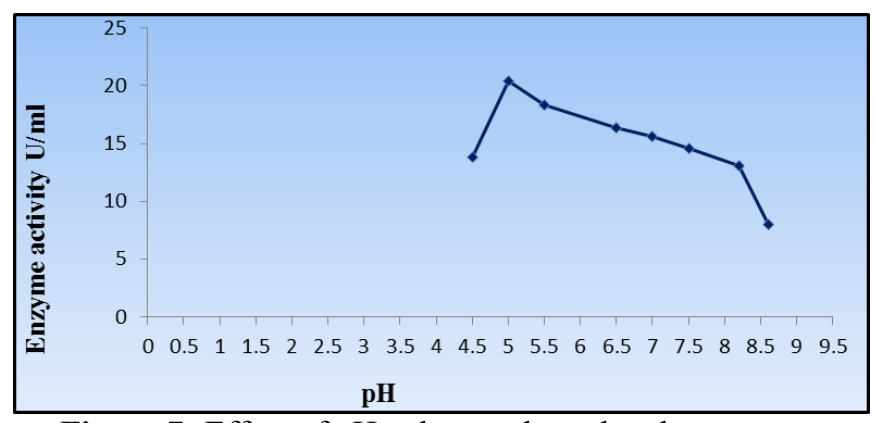

Figure 7: Effect of $\mathrm{pH}$ value on the polygalacturonase activity purified from $F$. sacchari.

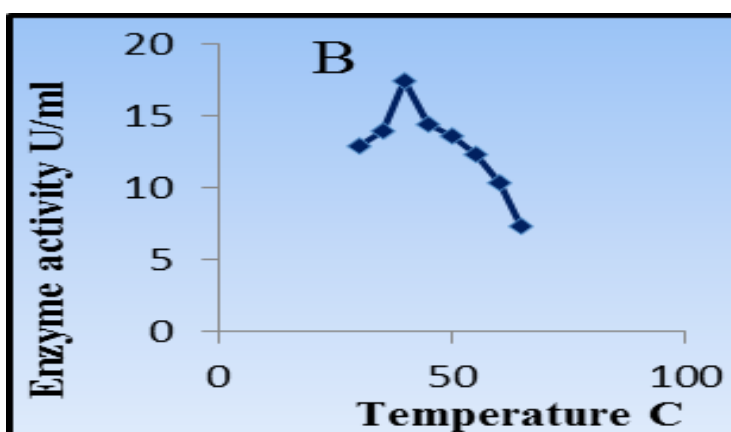

Figure 8: Optimum temperature of polygalacturonase activity purified from $F$. oxysporum. $\mathrm{A}=$ peak 1 and $\mathrm{B}=$ peak

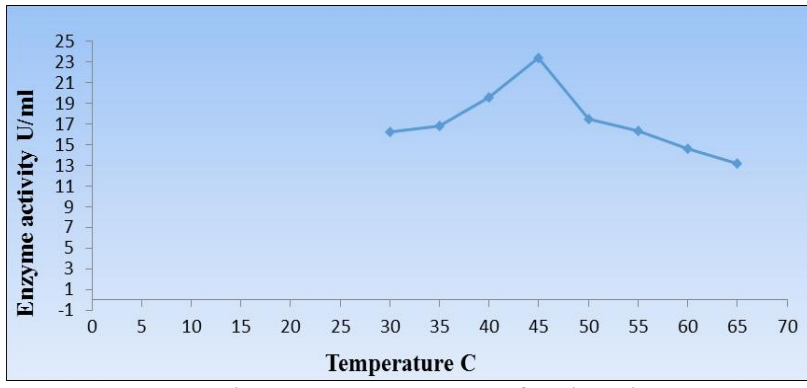

Figure 9: Optimum temperature of polygalacturonase activity purified from $F$. sacchari.

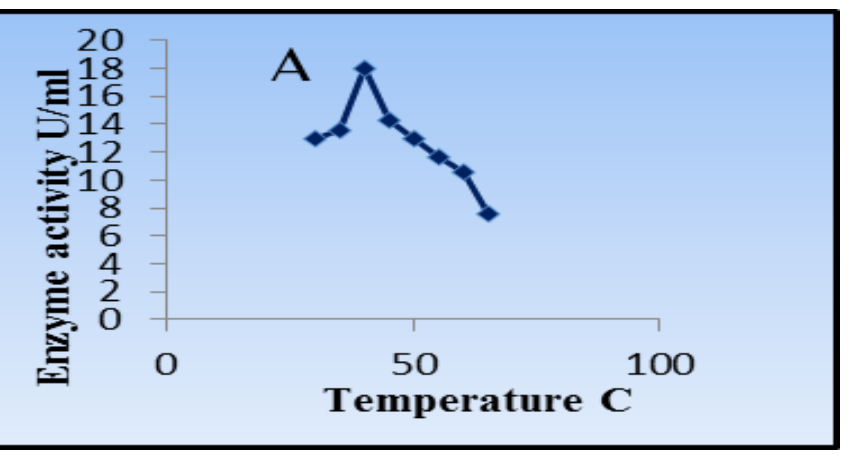

Table 1: Purification steps of polygalacturonase enzyme purified from F.oxysporum.

\begin{tabular}{|c|c|c|c|c|c|c|c|}
\hline Purification steps & $\begin{array}{l}\text { Volume } \\
\text { (Ml) }\end{array}$ & $\begin{array}{c}\text { Total } \\
\text { activity (U) }\end{array}$ & $\begin{array}{c}\text { Enzyme activity } \\
/ \mathrm{ml})\end{array}$ & $\begin{array}{l}\text { Protein concentration } \\
(\mathrm{mg} / \mathrm{ml})\end{array}$ & $\begin{array}{l}\text { Specific activity } \\
/ \mathrm{mg}\end{array}$ & yield & $\begin{array}{l}\text { Purification } \\
\text { fold }\end{array}$ \\
\hline Crude extract & 8 & 139.5 & 17.4375 & 26 & 0.670673 & 100 & 1 \\
\hline $\begin{array}{l}\text { Ammonium sulfate } \\
\text { precipitation } 70 \%\end{array}$ & 6.5 & 132.977 & 20.458 & 18.666 & 1.096003 & 95.324 & 1.6341843 \\
\hline $\begin{array}{c}\text { Ion exchange } \\
\text { chromatography } \\
\text { Peak1 }\end{array}$ & 3 & 61.8 & 20.6 & 6 & 3.43333 & 44.3011 & 5.11923 \\
\hline $\begin{array}{c}\text { Ion exchange } \\
\text { chromatography } \\
\text { Peak2 }\end{array}$ & 3 & 52.8 & 17.6 & 0.666 & 26.4 & 37.8 & 39.4 \\
\hline
\end{tabular}

Table 2: Purification steps of polygalacturonase enzyme purified from F.sacchari.

\begin{tabular}{|c|c|c|c|c|c|c|c|}
\hline Purification steps & $\begin{array}{c}\text { Volume } \\
(\mathrm{Ml})\end{array}$ & $\begin{array}{c}\text { Total activity } \\
(\mathrm{U})\end{array}$ & $\begin{array}{c}\text { Enzyme } \\
\text { activity (U/ml) }\end{array}$ & $\begin{array}{c}\text { Protein concentration } \\
(\mathrm{mg} / \mathrm{ml})\end{array}$ & $\begin{array}{c}\text { Specific } \\
\text { activity U/mg }\end{array}$ & yield & $\begin{array}{c}\text { Purification } \\
\text { fold }\end{array}$ \\
\hline Crude extract & 8 & 159.16 & 19.895 & 122 & 0.1630738 & 100 & 1 \\
\hline $\begin{array}{c}\text { Ammonium sulfate } \\
\text { precipitation } 70 \%\end{array}$ & 7.5 & 151.7175 & 20.229 & 78.666 & 0.2571505 & 95.323 & 1.576896 \\
\hline $\begin{array}{c}\text { Ion exchange } \\
\text { chromatography }\end{array}$ & 4.5 & 58.59 & 13.02 & 38 & 0.3426316 & 36.812 & 2.10108331 \\
\hline Gel filtration & 3 & 54.687 & 18.229 & 26 & 0.701115 & 34.35 & 4.29937556 \\
\hline
\end{tabular}

Volume 5 Issue 1, January 2016 


\section{International Journal of Science and Research (IJSR) \\ ISSN (Online): 2319-7064}

Index Copernicus Value (2013): 6.14 | Impact Factor (2014): 5.611

Diagnosis by polymerase chain reaction technique (PCR)

The genomic DNA of Fusarium species (F.oxysporum, F.sacchari, F.globosum, F.proliferatum, and F.solani) was isolated and gene coding for (pgxl) was amplified by PCR. This result showed that the gene pgxl encoded for polygalacturonase enzyme is present. The PCR primers designed from the conserved region of known fungal produced $1700 \mathrm{pb}$ product from the genomic DNA of F.oxysporum and 1400 bp product from the genomic DNA of F.sacchari, as shown in figure 10 .

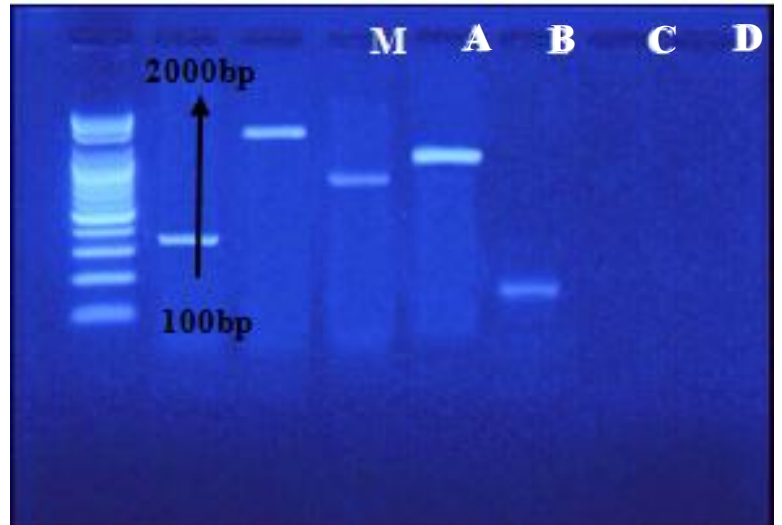

Figure 10: Agarose gel electrophoresis of PCR amplified products of F.oxysporum and F.sacchari, M= DNA ladder with molecular weight (100-2000bp), A= PCR products pgxlgene from $F$.solani $\mathrm{B}=$ PCR products $p g x l$ gene from F.oxysporum, $\mathrm{C}=$ products pgxlgene from $F$.proliferatum $\mathrm{D}=$ PCR products of pgx 1 gene from $F$.sacchari and $\mathrm{E}=$ products pgxlgene from $F$.globosum.

\section{Discussion}

\section{Purification of polygalacturonase enzyme Precipitation with ammonium sulphate}

Ammonium sulphate is a common salt using in protein concentration in view of higher solubility, cheap, and stabilizes protein structure. Crude polygalacturonase of F.oxysporum was concentrated with $70 \%$ ammonium sulphate. This result is in agreement with [6] who reported that the polygalacturonase was precipitated at $40-80 \%$ ammonium sulphate saturation with the highest activity obtained at $70 \%$ saturation from Aspergillus niger (SA6) and other studies by the same research have shown that polygalacturonase can be precipitated between $0-90 \%$ of ammonium sulphate depending on the source of enzyme.

In the case of F.sacchari, the maximum specific activity was obtained at $90 \%$, these results are consistent with those obtained from [7] who found around 1.5 fold purification levels with $85 \%$ of enzyme recovery when they used $90 \%$ ammonium sulphate saturation to precipitate polygalacturonase from Aspergillus niger. This step was performed as a purification step to remove un wanted substances and protein as well as concentration step by resuspending the pellet in a less amount of buffer. Ammonium sulphate precipitation (salting out) is useful for concentrating dilute solutions of protein. It is also useful for fractionating a mixture of proteins since large proteins tend to precipitate first while smaller ones will stay in solution. After a protein has been precipitated and taken back up in buffer the solution contained a lot of residual ammonium sulphate which was bound to the protein. [8].

\section{Ion exchange for polygalacturonase purified from} F.oxysporum and F.sacchari

Ion exchange chromatography profile of Polygalacturonase on DEAE-cellulose showed that the enzyme eluted in the flow through. This step was used to purify protein, that indicated decrease in total protein and total activity, whereas specific activity increased .In this study, the results showed isoforms of PGase. These results in agreement with those results obtained by [9] that reported most PGs so far have several isozymes. Isoenzymes can be defined as the several forms of an enzyme that all catalyze the same reaction but may differ in reaction rate, $\mathrm{pH}$, temperature, electrophoretic mobility and immunologic properties [10].

Most fungal organisms produce multiple forms enzyme [11] suggesting either that several genes are involved, or that post -translational modification results in different physical properties of the enzymes. In addition, these studies also compatible with other results reported by[12], which refer to various numbers of PGases with different specific activity, were reported from Aspergillus niger. According to [13] variation in the isoforms of extracellular enzymes obtained by solid state fermentation can be attributed to alteration of water potential that results in changes in the permeability of fungal membranes, limitation of sugar transport and presence or absence of inducer.DEAE-cellulose chromatography has many advantage, including high resolution power, high capacity, easy handling, good separation, ability of reactivation for using many times besides the simplicity of separation principle which depending on charge differences[14].

\section{Gel filtration chromatography of F.sacchari}

Gel filtration chromatography by using sephadex G-200 Colum was the next step of PGase purification from F.sacchari. In this study, the results showed one peak of protein with high specific activity. These results considered with results presented [15] who reported PGase enzyme was purified from Acrophialo nainiana by using sephadex G-200 has one peak of protein and one peak of activity. The degree of purification of PGase based on specific activity from resistant and susceptible varieties, the fractionating of ammonium sulphate on sephadex G-200 tend to point to the pattern of synthesis of PGase. The position of enzyme on the chromatography suggested that only PGase was produced during growth [16].

Sephadex G-200 has many advantages included fast run high recovery separation, simple preparation and its stability for long time permits reusing of the gel many times in protein separation [17].

\section{Polyacrylamide gel electrophoresis technique}

The SDS-PAGE revealed an apparent molecular weight of 53KD and 41KD for F.oxysporum and F.sacchari respectively. These results in this study agreement with [18] who reported that molecular weight of PGase enzyme at range $35-80 \mathrm{KD}$. The majority of purified fungal PGase have molecular weight in range from 25-80KD [19]. 


\section{International Journal of Science and Research (IJSR) \\ ISSN (Online): 2319-7064 \\ Index Copernicus Value (2013): 6.14 | Impact Factor (2014): 5.611}

The appearance of many protein bands along gel is imputed to that crude extract contain large number from different proteins with different molecular weight. Whearse the other samples gave only single band, these mean that there is no contamination from other proteins. Other studies suggested that molecular weight of PGases ranging from 35-496 Dalton's for different species of fungi [20] Of all the reasons adduced by [21] for the differences in molecular weight, nature and type of organisms used, substrates employed and analytical methods in addition to monomeric units of the polypeptides could justify the differences.

\section{Characterization of polygalacturonase from F.oxysporum and F.sacchari}

\section{The optimum pH for enzyme activity}

Effect of $\mathrm{pH}$ on purified PGase activity was determined; it was observed that PGase has the best activity in $\mathrm{pH} 5$ and 6 . It is not too sensitive to $\mathrm{pH}$ variation but it is more active at $\mathrm{pH} 5$ and 6 than other values, this may give a conclusion that the fungus favored environmental conditions at $\mathrm{pH} 5$ and 6 for degradation of lipids and utilization as carbon source or for their metabolic process.

Fungal PGases are known to operate mild acidic environment. $\mathrm{pH}$ optima for $23 \mathrm{PGases}$ isolated from various species with a range of $\mathrm{pH} 3.8-6.5$. These results were compatible with our results in this study. The optimum $\mathrm{pH}$ and possible amino acids in the active site of PGase is in agreement with those reported by previous workers. Other results showed similar observation of this study, which reported Pencillium viridicatum showed an optimum $\mathrm{pH}=6$ as mentioned by [22], and $\mathrm{pH}$ 4.5-5 for Pencillium sp[23]. The effect of $\mathrm{pH}$ on structure and activity of $\mathrm{PG}$ from A.niger was demonstrated by [24]. They evidenced that the active conformation of PGase was favored $\mathrm{pH}$ between 3.56 ; alteration in the secondary and tertiary structures resulted in at $\mathrm{pH}=5-7$.

\section{The optimum temperature for enzyme activity}

Temperature is a very important factor for microbial growth as well as microbial product formation and it varies from each of microorganism. In fact, slight changes in growth temperature may effect on enzyme activity [25]. In this study, the results showed optimum temperature of enzyme activity was 40,45 , and $50^{\circ} \mathrm{C}$. Regarding the influence of temperature was demonstrated, these results are agreement with [26] In addition, PGase produced by A.flavus, A.fumigatus exhibited maximum activity at 40 and $45^{\circ} \mathrm{C}$ respectively [27] Optimal temperature of PGase showed a range from $40-60^{\circ} \mathrm{C}$. These optimal temperatures were similar to those observed for PGase from Streptomyces erumpens [28].

Diagnosis by Polymerase chain reaction technique (PCR) Exo polygalacturonase is important virulence factor in fungi and bacteria [29]. A single gene in many Fusarium species such as F.oxysporum, for this reason, encodes PGase the pgxl gene has been proposed as a molecular marker for taxonomic studies of Fusarium species [30,31]

In this study, the results showed that the gene encoding exo polygalacturonase of F.oxysporum and F.sacchari is present.
These results are compatible with [32] who revealed that the gene pgxl is present in some Fusarium species with molecular weight $1400 \mathrm{bp}$. Other studies revealed that the molecular weight of products that obtained from F.oxysporum was $1.793 \mathrm{bp}$ [33].

\section{References}

[1] Samantha, A.; Larroche, C.; Pandey, A (2006). Microbiology and industrial biotechnology of foodgrade proteases: a perspective. Food Technology and Biotechnology, 44 (2): 211-220.

[2] Dias, D. R.; Abreu, C. M. P.; Silvestre, M. P. C and Schwan, R. F. (2010). In vitro protein digestibility of enzymatically pre-treated bean (Phaseolus vulgaris L.) flour using commercial protease and Bacillus sp. Protease. 30 (1): 94-99.

[3] Gummadi SN, Panda T (2003). Purification and biochemical properties of microbial pectinases-a review. Process Biochem. 38: 987-996.

[4] Di Matteo (2006). Polygalacturonase-inhibiting protein (PGIP) in plant defense: a structural view. Phytochemical. 67: 528-533.

[5] Gummadi, Sathyanarayana N., and T. Panda (2003). "Purification and Biochemical Properties of Microbial Pectinases-a Review" Process Biochemistry 38(7): 987-96.

[6] Buga, M.L., Ibrahim, S. and Nok, A.J. (2010). Partially purified polygalacturonase from Aspergillus niger (SA6). African Journal of Biotechnology, 9 (52):8944-8954.

[7] Hara .T. Lim. J.Y.Fujio. Y. and Ueda S.( 1984) Nipp. Shok. Kog. Gakk. 31, 581.

[8] Rosenberg. I. and Birkhauser I. M. (2004) Springer. 520.

[9] Cabanne, C., Doneche B. (2002). Purification and characterization of two isozymes of polygalacturonase from Botrytis cinerea. Effect of calcium ions on polygalacturonase activity. Microbiology Research 157, 183-189.

[10] Anderson, MR.; Nielsen, ML; Nielsen, J. (2008).Metabolic model integration of the bibliome, genome, metabolome and reactome of Aspergillus niger. Molecular systems Biology.178 (4):1-13.

[11] Devi N.A., AppuRao A. G. (1996). Fractionation, purification, and preliminary characterization of polygalacturonase produced by Aspergillus carbonarius. Enzyme Microbial Technology 18, 59-65.

[12] Murad HA, Azzaz HH (2011). Microbial pectinases and ruminant nutrition. Res. J. Microbiol. 6: 246-269.

[13] Viniegra-Gonzalez.G.; Favela-Torres.E. (2006). Food Techno Biotechnol .44, 397-406.

[14]AL-Kubaissy , Khalid (2011) Biochemistery , third edition, ALBalkaa

[15] Celestino, S.M.C., Maria de Freitas, S., Medrano, F.J., Valle de Sousa, M., Filho, E.X.F. (2006). Purification and characterization of a novel pectinase from Acrophialophora nainiana with emphasis on its physicochemical properties. J. Biotechnol. 123, 33-42.

[16] Juwon.A.D; Akinyosoye. F.A; and Kayode.O.A. (2012). Purification, characterization, and application of polygalacturonase from Aspergillus niger CSTRF.8 (3), 175-183.

\section{Volume 5 Issue 1, January 2016}




\section{International Journal of Science and Research (IJSR) \\ ISSN (Online): 2319-7064 \\ Index Copernicus Value (2013): 6.14 | Impact Factor (2014): 5.611}

[17] Charlotte, W. P. and Kathleen, C. (2009) Essential Biochemistry, John Wiley and (USA).

[18] De Vries RP, Visser J (2001) Aspergillus Enzymes Involved in Degradation of Plant Cell Wall Polysaccharides. Microbiol. Mol. Biol.

[19] Mohamed, S.A., Al-Malki, A.L. and Kumosani, T. A. (2009). Characterization of a Polygalacturonase from Trichoderma harzianum Grown on Citrus Peel with Application for Apple Juice. Australian Journal of Basic and Applied Sciences, 3(3): 2770-2777.

[20] Jayani, R.S.; Saxena, S. and Gupta, R. (2005). Microbial pectinolytic enzymes: A review. Process Biochemistry 40:2931-2944.

[21] Oyede, M. A. (1998). Studies on cell wall degrading enzymes associated with degradation of cassava (Manihot esculenta) tubers by some phytopathogenic fungi. Ph. D Thesis, Obafemi Awolowo University, Nigeria.

[22] Silva.D. Martins; ES. Leite; RSR. Silva. R. Ferreira; Gomes. E, (2007) Process Biochem. , 42, 1237-1243.

[23] Martin, N; Souza, SR; Silva, R; and Gomes, E (2004).Optimization and characterization of polygalacturonase enzyme produced by gamma irradiationPencilliumcitrinum.Brazil.Arch.Biotechnolog y.813-819.

[24] Jyothi; TC, Singh, SA; Rao, AGA. (2005). Intern J Biol Macromol., 36,3107.

[25] Syarifah, A. R., Darah, I. and Ibrahim, C. O. (2012). Mannanase production by Aspergillus niger USM F4 via solid substrate fermentation in a shallow tray using palm kernel cake as a substrate. Malaysian Journal Microbiology 8(4), 273-279.

[26] Palaniyappan, M.; Vijayagopai, V.; Viswannathan, R. and Viruthagiri, T. (2009). Screening of natural substrates and optimization of operating variables on the production of pectinase by submerged fermentation using Aspergillus niger MTCC 281. African Journal of Biotechnology 8(4): 682-686.

[27] Arotupin, D. J. (2007). Effect of different carbon sources on the growth and polygalacturonase activity of Aspergillus flavus isolated from cropped soils. Research Journal of Microbiology 2(4): 362-368.

[28] Kar S, Ray RC (2011). Purification, characterization and application of thermo stable exo-polygalacturonase from Streptomyces erumpens MTCC 7317. J. Food Biochem. 35: 133-147.

[29] Huang Q., and Allen C. (2000). Polygalacturonase are required for rapid colonization and full virulence of Ralstonia solanacearum on tomato plants. Physiological and Molecular Plant Pathology 57: 7783.

[30] Posada M.L., Patiño B., De la Heras A., Mirete S., Vazquez C., Gonzalez-Jaen M.T., (2000). Comparative analysis of an endo polygalacturonase coding gene in isolates of seven Fusarium species. Mycological Research 104: 1342-1347.

[31] Daroda L., Hahn K., Pashkoulov D., Benvenuto E. (2001).Molecular characterization and in planta detection of Fusarium moniliforme endo polygalacturonase isoforms. Physiological and Molecular Plant Pathology 59: 317-325.

[32] Caprari C., Richter A., Bergmann C., Lo Cicero S., Salvi G., Cervone F., De Lorenzo G. (1993). Cloning and characterization of the gene encoding the endo polygalacturonase of Fusarium moniliforme. Mycological Research 97: 497-505.

[33] Hirano, Y. and Arie, T. (2009). Variation and phylogeny of Fusarium oxysporum isolates based on nucleotide sequences of polygalacturonases.24 (2), 113 120. 